\title{
Re: Steerable Antegrade Stenting: A New Trick of the Trade
}

\author{
Udo Nagele, Aristotelis G. Anastasiadis, Bastian Amend, David Schilling, Marcus Kuczyk, Arnulf \\ Stend, Karl-Dietrich Sievert
}

Department of Urology, University of Tuebingen, Germany

Int Braz J Urol, 33: 389-394, 2007

To the Editor:

The authors describe as a novelty the percutaneous kidney punction with the patient placed in supine position to carry out in an antegrade way the ureteral stenting (1). However we described this procedure 20 years ago (2), in a work that was published in many important urological journal such as the Journal of Urology (3), the Journal of Endourology (4) and the Brazilian Journal of Urology (5) among others.

Among the advantages demonstrated by the percutaneous kidney approach with patient in supine position, (which have been referenced in our previous communications) the possibility exists of simultaneously performing combined endoluminal instrumentation, which can even carry out with a rigid transuretral ureterorrenoscopy at the same time as a percutaneous nephroscopy. This fact has been recently highlighted by many authors, notably including Ibarlucea et al. (6) and Scarpa \& Scoffone (7).

In contrast to the opinion of the authors of this paper and of Park (8) who made the first editorial comment to this process, we can confirm that with the patient in supine position does not result in the essential sonographic control in order to perform the percutaneous punction of the kidney. We only make use the sonographically guided renal puncture in extreme circumstances. In the majority of instances we carry out the punction under a simple radioscopic control in $\mathrm{P}-\mathrm{A}$, without having to change the position of the $\mathrm{C}$ arm which is precisely one of the multiple advantages of this procedure.

Liatsikos \& Voudoukis (9), who make the second editorial comment attribute the origin of the combined technique (called "Redezvous Technique") to Marci et al. (10), who described it for the ureteral stenting in 2005. Nevertheless, in our work published in the Journal of Endourology in 1990 (4) we already showed a radiological image with a face to face in to the kidney of a percutaneous nephroscope and a rigid transurethral ureterorenoscope, when referenced the advantages of working both, radiologically and edoscopically, simultaneously from both fields.

\section{REFERENCES}

1. Nagele U, Anastasiadis AG, Amend B, Schilling D, Kuczyk M, Stenzl A, Sievert KD: Steerable antegrade stenting: A new trick of the trade. Int Braz J Urol. 2007; 33: 389-94.

2. Valdivia-Uría JG, Lanchares E, Villarroya S: Nefrolitectomía percutánea: Técnica simplificada (nota previa). Arch Esp Urol. 1987; 40: 177.

3. Valdivia-Uría JG, Valle Gerhold J, López JA: Technique and complications of percutaneous nephroscopy: experience with 557 patients in supine position. J Urol. 1998; 160: 1975-8.

4. Valdivia-Uría JG, Valer J, Villarroya S: Why is percutaneous nephroscopy still performed with patient prone? J Endourol. 1990; 4: 350-9.

5. Valdivia-Uría JG, Valle J, López JA: Técnica de la nefroscopia percutánea en posición supina. J Bras Urol. 1999; 25: 263-7.

6. Ibarlucea G, Scoffone C M, Cracco C M: Supine Valdivia and modified lithotomy position for simultaneous anterograde and retrograde endourological access. BJU Int. 2007; 100: 233-6.

7. Scarpa RM, Scoffone CM: Galdakao-modified supine Valdivia lithotomy position for endoscopic combined 
intra renal surgery (ECIRS). Multilingual DVD presentation. Karl Storz Endoskope. Tuttlingen. Endopress 2007.

8. Park S: Editorial Comment in: Steerable antegrade stenting: A new trick of the trade. Int Braz J Urol. 2007; 33: 393-4.
9. Liatsikos EN, Voudoukis TH: Editorial Comment in: Steerable antegrade stenting: A new trick of the trade. Int Braz J Urol. 2007; 33: 394.

10. Macri A, Magno C, Certo A: Combined antegrade and retrograde ureteral stenting: The rendezvous technique. Clin Radiol. 2005; 60: 457-60.

Dr. José Gabriel Valdivia Uría

Department of Urology

Universitary Hospital Lozano Blesa

Saragossa, Spain

E-mail: jvaldivia@salud.aragon.es

\section{Re: Lack of Association between Matrix Metalloproteinase-1 (MMP-1) Promoter Polymorphism and Risk of Renal Cell Carcinoma}

Michelly F. Piccoli, Marcia Figueira, Cassio Andreoni, Julio T. Marumo, Nestor Schor, Maria H. Bellini

Section of Nephrology (MFP, MF, NS, MHB) and Section of Urology (CA), Federal University of Sao Paulo, UNIFESP, and Institute of Energetic and Nuclear Research (JTM, MHB), Sao Paulo, SP, Brazil

Int Braz J Urol, 33: 622-629, 2007

To the Editor:

Matrix Metalloproteinases (MMPs) are a family of extracellular matrix degradative enzymes physiologically involved in tissue development and remodeling. Now they are being widely studied for their potential role in the progression and metastasis of many tumors (1).
Indeed degradation of extracellular matrix is one of the crucial and early steps in many carcinomas. The role of the huge family of these enzymes and their inhibitors in cancer cells invasion, metastasis (2), proliferation and angiogenesis (3) is probably much more complex than it seems and still needs to be clarified. 